\title{
The simulation of the stress field of welded joint containing discontinuity No 1014
}

\section{Keywords:}

FEM Simulation;

stress concentration in the welds; discontinuities;

fracture mechanic

\begin{abstract}
This paper contains the results simulation and linear elastic fracture mechanic (LEFM) calculation of the welded joint contains it discontinuity 1014. The model base material C-Mn non-alloy steel S235JRG2 according to EN 10025-2 and consumable GMAW wire electrode G3Si1 according to EN ISO 14341 was prepared. Due to stress singularity effect located at the tip of the crack, the Huber-Mises-Hencky $(\mathrm{H}-\mathrm{M}-\mathrm{H})$ hypothesis cannot be used, so that the stress intensity factor $\left(\mathrm{K}_{\mathrm{I}}\right)$ and fracture toughness $\left(K_{I C}\right)$ was applied. The LEFM analysis showed the range where the existence of crack can be acceptable. Based on well-known LEFM issue the verification of simulation program was performed. The stress intensity factor $\left(K_{l}\right)$ values was obtained from FEM simulation process.
\end{abstract}

\section{Introduction}

Models and their mathematical methods of description for centuries have had a very limited application due to the huge amount of algebraic operations necessary to obtain a satisfactory result. This state of affairs was changed by the invention of the semiconductor, the construction of the transistor in 1947 and the first computer (FEM) in the early 1960s. Since the mid-twentieth century, thanks to the theoretical work of many outstanding scientist, the FEM method has been developed continuously. Their effort was realized only thanks to unprecedented progress in the field of computer techniques. One of the most important articles in this field from the mid-1960s was the publication of "Computer Experiments in Fluid Dynamic" by Harlow and Fromm. Consisting in the creation in very short time the third pillar of the science. From that time, in addition to the theory and experiment, a computer simulation is accessible. This article presents the FEM method in the field of welding.

\section{Description of the welded joint}

For the static simulation the model of $200 \mathrm{~mm}$ length butt-welded joint was used. It consists of two $40 \mathrm{~mm}$ thickness bars with accordance figure 1. For the purpose of simulation the model of base material non-alloy steel S235JRG2 according to EN 10025-2 [1] and consumable GMAW wire

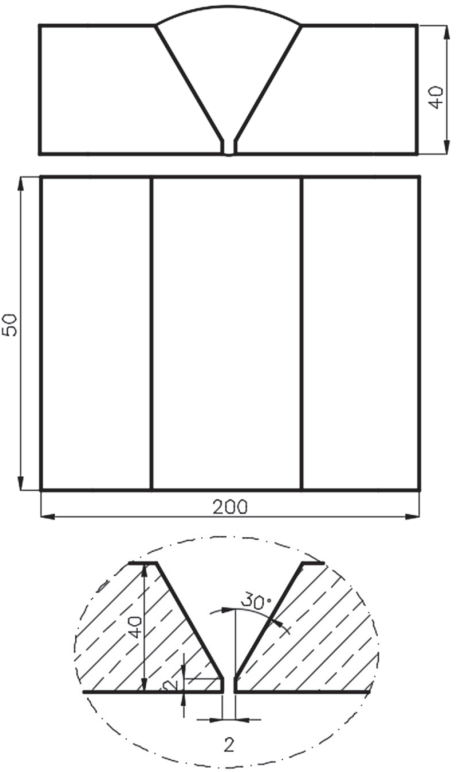

Fig. 1. The welded joint

electrode G3Si1 according to EN ISO 14341 [2] was prepared.

Regardless of that cracks is not allowed at any quality level EN ISO 5817 [3], the analysis was performed to figure out the stress fields around this type discontinuity. The parameters of the welded joint model shown in Figures 2 and 3

mgr inż. Jerzy Nawrocki - Bilfinger-Tebodin Poland; prof. dr hab. inż. Jacek Słania - Czestochowa University of Technology 
is as hereunder.

- finite element size $=0.3 \mathrm{~mm}$,

- number of nodes $=156948$,

- number of finite elements $=113815$.

A division into tetragonal finite elements was applied, taking into account the principle of density of the grid in places of special importance. It has always been the area of occurrence of the analysed discontinuity.
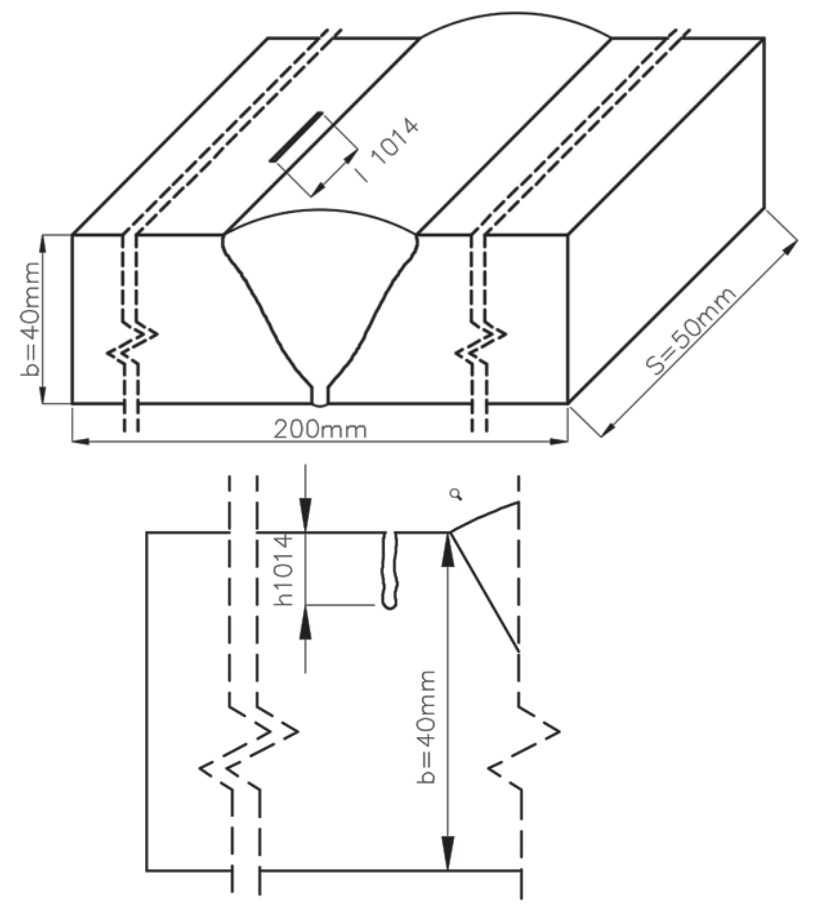

Fig. 2. The draft of the discontinuities No 1014

\section{Analysis of discontinuities using the fracture mechanics method}

Due to stress singularity effect located at the tip of the crack, the Huber-Mises-Hencky $(\mathrm{H}-\mathrm{M}-\mathrm{H})$ hypothesis cannot be used. The fracture mechanics method which operates on another type approach shall be used. It is stress intensity factor $\left(\mathrm{K}_{\mathrm{I}}\right)$ and fracture toughness $\left(\mathrm{K}_{\mathrm{I}}\right)$. The finite dimensions of the welded joint was taken into account in this simulations. The ready-made formulas for specific cracks-load cases configuration can be found in the literature [4].

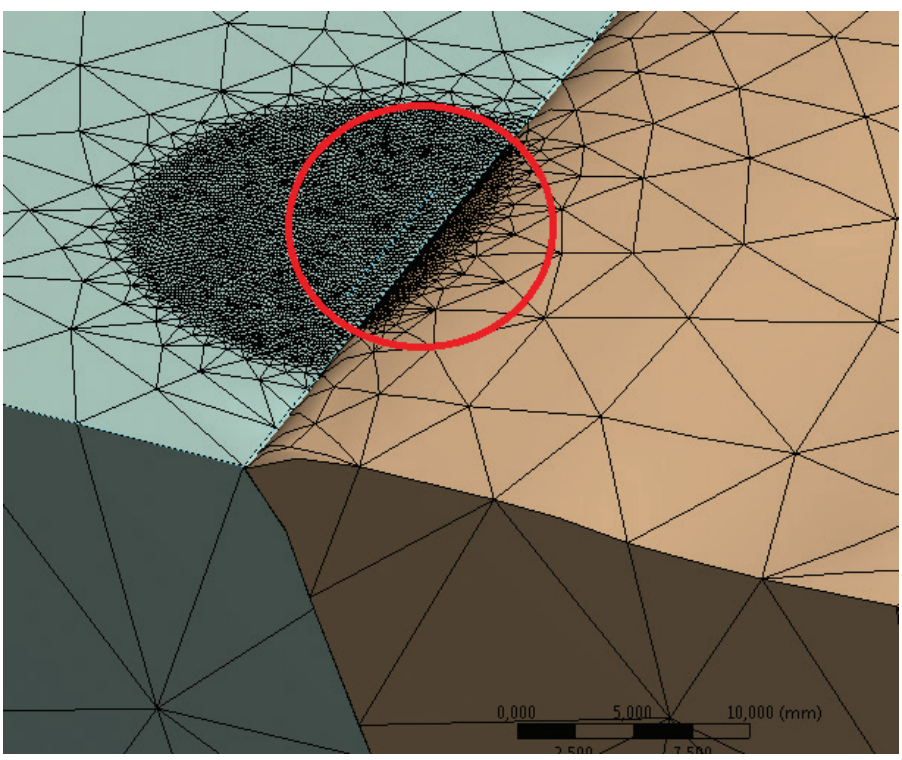

Fig. 3. Example of density of the grid in the discontinuities
The nominal cross-section is equal to the total area of the cross-section reduced by the area of discontinuity:

$$
A_{\text {nom }}=S b-I_{1014} h_{1014}
$$

where:

$\mathrm{S}$ - width of the joint [mm],

b - height of the joint [mm],

$\mathrm{I}_{1014}$ - crack length [mm],

$\mathrm{h}_{1014}$ - crack depth [mm].

The condition of the necessary balance is:

$$
\sigma A=\sigma_{\text {nom }} A_{\text {nom }}
$$

As a consequence, the joint's strength is:

$$
\sigma_{\text {nom }}^{\mathrm{kr}}=\text { UTS }\left(1-A_{\text {nom }} / \mathrm{Sb}\right)
$$

To evaluate the stresses created by the discontinuity no. 1014 the single edge notch and criterion failure $K_{1}=K_{I C}$ is adapted. The value of the fracture toughness $\mathrm{K}_{\mathrm{IC}}=217 \mathrm{MPa} \cdot \mathrm{m}^{0.5}$ suitable for C-Mn steel was adopted from publication [5]. The capacity of the welded joint with discontinuity can be describe as hereunder:

$$
\begin{aligned}
\sigma_{\mathrm{KI}}^{\mathrm{kr}}= & \left.\mathrm{K}_{\mathrm{IC}} / \sqrt{\left(\Pi \mathrm{h}_{1014}\right.}\right) \times 1 /\left[1,12-0,23\left(\mathrm{~h}_{1014} / \mathrm{b}\right)+10,55\left(\mathrm{~h}_{1014} / \mathrm{b}\right)^{2}-\right. \\
& \left.-21,72\left(\mathrm{~h}_{1014} / \mathrm{b}\right)^{3}+30,39\left(\mathrm{~h}_{1014} / \mathrm{b}\right)^{4}\right]
\end{aligned}
$$

The calculation were made for the depth of the crack in the range from 5 to $75 \%$ of the joint's thickness. The graph (Fig. 4) shows three curves:

- red - tensile strength of S235 steel equal to $360 \mathrm{MPa}$,

- green - static critical strength $\sigma_{\text {nom, }}^{\mathrm{kr}}$

- blue - critical strength from the point of view of fracture mechanics $\sigma_{\mathrm{K}_{1}}^{\mathrm{kr}}$.

In Figure 4, that the welded joint with crack up to $20 \mathrm{~mm}$ deep will break due to exceeding of the tensile strength of the base material. From the depth $20 \mathrm{~mm}$ the maximum strength

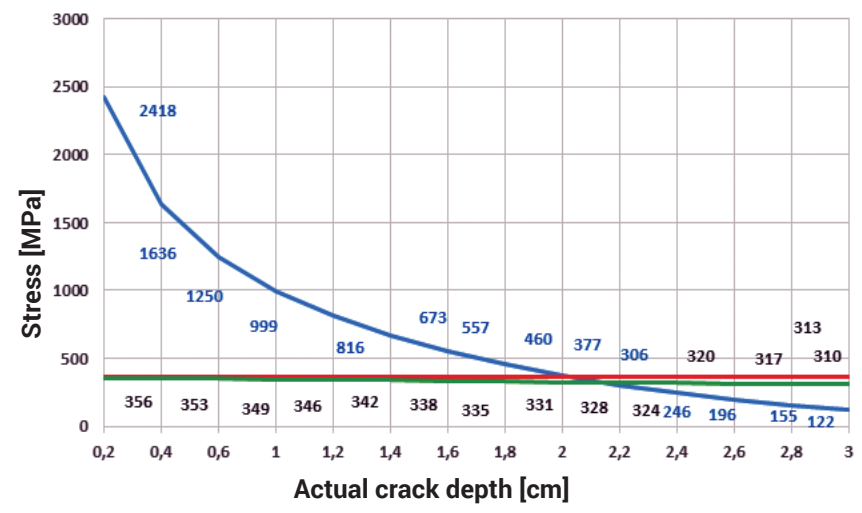

Fig. 4. Strength of the joint according to the fracture mechanics

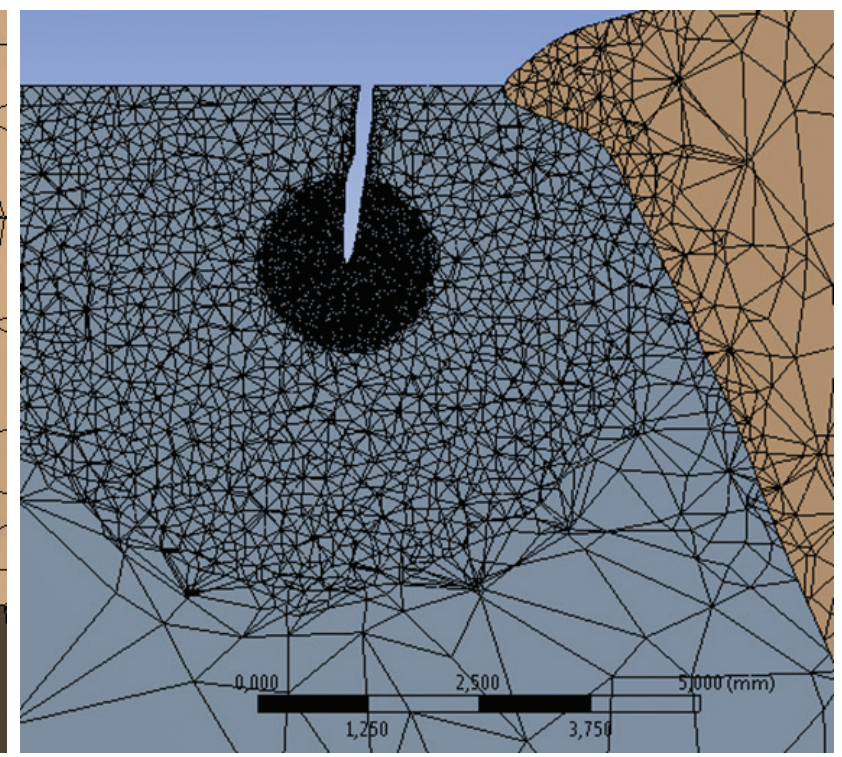


will decrease significantly. For such case the safe working range is below the blue line.

\section{Plastic zone of discontinuities}

FEM simulation results as well as experimental data indicates the plastic zone at the tip of the crack where the stresses are so high, that the approaches of elasticity theory and linear-elastic fracture mechanic can not be used. However implementation of the concept small plastic area (SPA) located at the tip of the crack (Fig. 5) may solve such problems. There are, however, two conditions: firstly, the SPA area must be much smaller than the crack depth and width of the joint itself, and secondly, the load may not be too large, so that
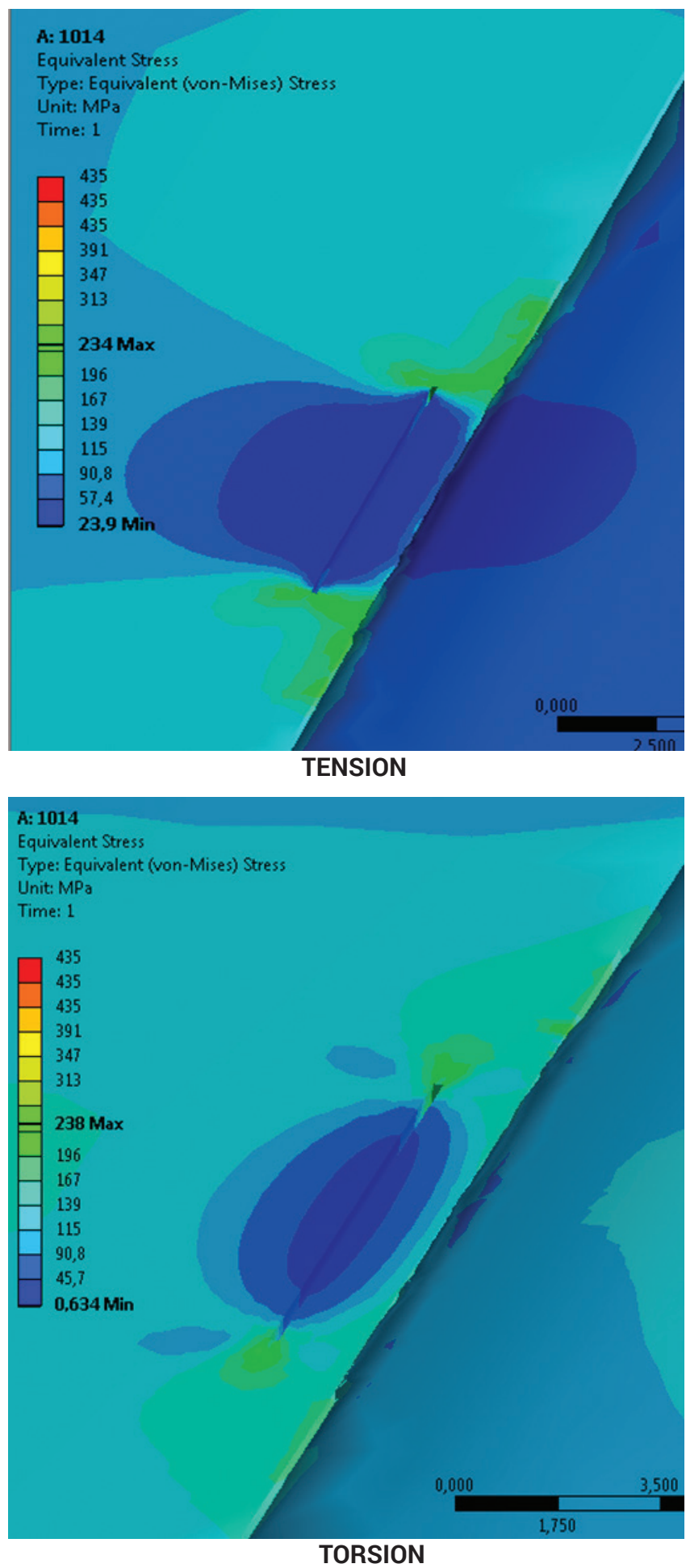

Fig. 5. The shape of the butt joint stress field for $50 \%$ WWN - top view the tension generated on the tip of the crack does not affect the stress field too much [6]. Assuming that the metal of the joint is perfectly elastic and plastic, the actual stresses cannot exceed the yield strength of the base material. The main problem in the correct interpretation of longitudinal crack simulation is therefore to determine the length of the plastic zone. According to the so-called Irwin's first approximation, the crack and its direct proximity to the stress will be approximately constant at the apex, while outside this area they will decrease as it moves away from it.

If the values of the stress field exceed the yield point, the only variable will be the area of the SPA zone. The definition of a conventional yield stress $\mathrm{YS}_{0.05}$ according to EN ISO 6892-1:2016-09 [7], which determines this stress as giving $0.05 \%$ strain, was used as a criterion. For the butt-joint analysed, where the crack is in the native material of S235 steel with typical parameters $(E=210 \mathrm{GPa}, \mathrm{v}=0.3)$, the elongation $\varepsilon$ for the yield point is $225 / 210000=0.00107(0.107 \%)$. Therefore, it was assumed that the plasticisation of the native material will start at the place where the simulation will obtain elongation values above 0.00107 .

\section{Simulation of welded joint model}

For the purpose of the simulation the model of the crack whose width at the tip was $0.02 \mathrm{~mm}$ was prepared. It is known from the practice that the depth of the 1014 discontinuity should not exceed $2 \mathrm{~mm}$, so this value has been accepted for calculations.

The series of simulation was made for two load combinations: axial tension and torsion (Fig. 5). In order to examine the dependence of the shape and surface of the plastic zones of PSA on the applied load, eight load steps from 10 to $80 \% \mathrm{YS}_{0.2}$ of the base material determined as the stress utilization coefficient were used (Fig. 6).

\section{Stress intensity factor}

The Anysy 18.1 academic program used in this paper has been widely used since early 1970's, therefore the verification of result quality is formality only. Nevertheless it was done to fulfilled the principles of the simulations process. For the purpose of the verification the well-known issue from fracture mechanic was used (Fig. 7). The model was divided into 5160 elements and 4323 nodes using hex-dominant method with more density at the tip of the crack.

The series of simulations was made at the close contour of the crack. In the context of FEM simulation, where the issue of error of discretization plays a significant role, 6 contours were used, after which the said parameter was calculated. The contour no. 1 is closest to the face of the crack, where the grid of elements and the stress field are the most distorted by them.

However, the results of the $K_{1}$ coefficient for contours 2 to 6 will be similar to each other. As a rule, the outermost contour is rejected because it is farthest from the front of the crack.

The value of the stress intensity coefficient for the analysed case can be determined in accordance with [8]:

$$
\begin{aligned}
\mathrm{K}_{\mathrm{l}}= & \sigma \sqrt{ } \text { Па }\left[1,122-0,231(\mathrm{a} / \mathrm{b})+10,550(\mathrm{a} / \mathrm{b})^{2}-21,710(\mathrm{a} / \mathrm{b})^{3}+\right. \\
& \left.+30,382(\mathrm{a} / \mathrm{b})^{4}\right]
\end{aligned}
$$

where:

$\sigma-$ tensile stress [MPa],

a - crack depth [mm],

$\mathrm{b}$ - plate width [mm],

$\mathrm{h}$ - distance from applying the tensile force [mm]. 

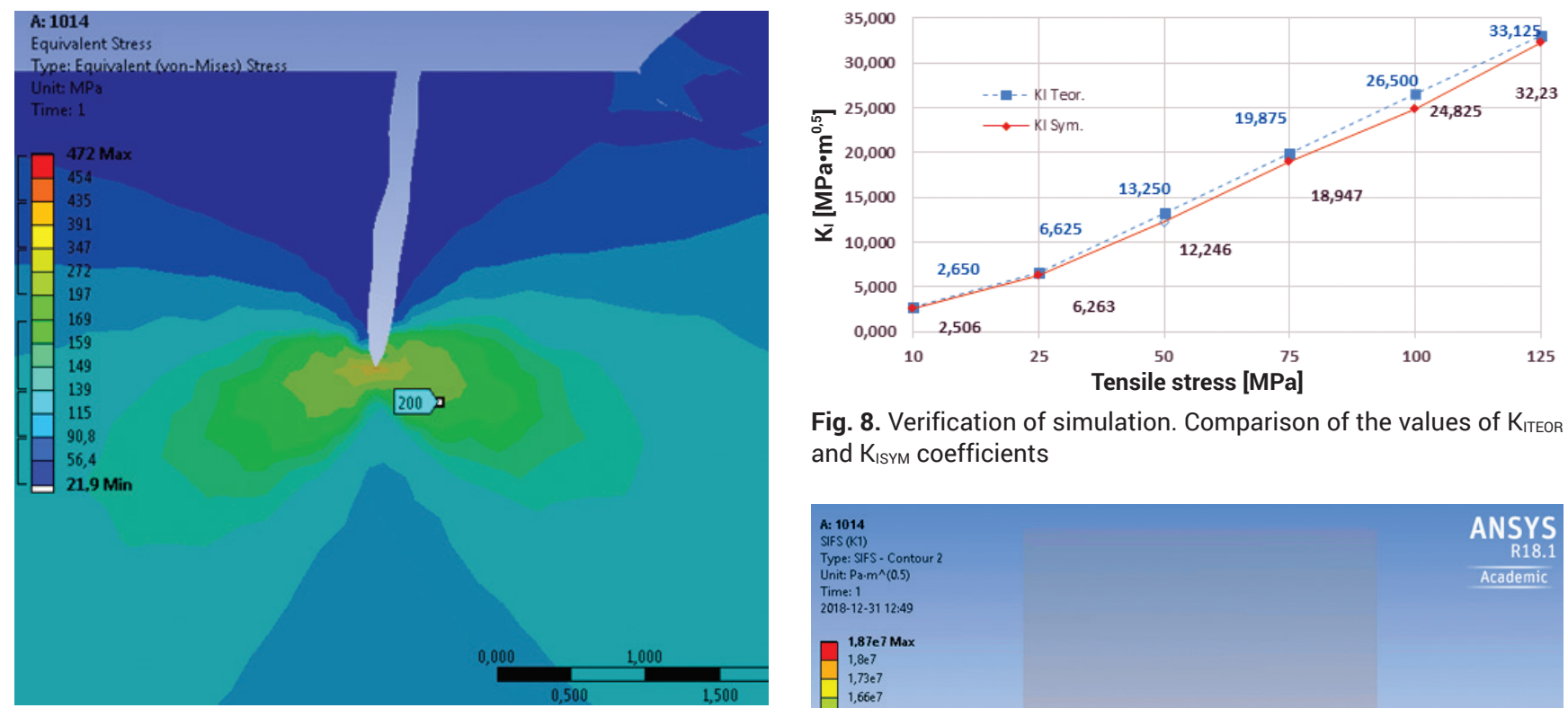

Fig. 8. Verification of simulation. Comparison of the values of $\mathrm{K}_{\text {ITEOR }}$ and $\mathrm{K}_{\mathrm{ISYM}}$ coefficients
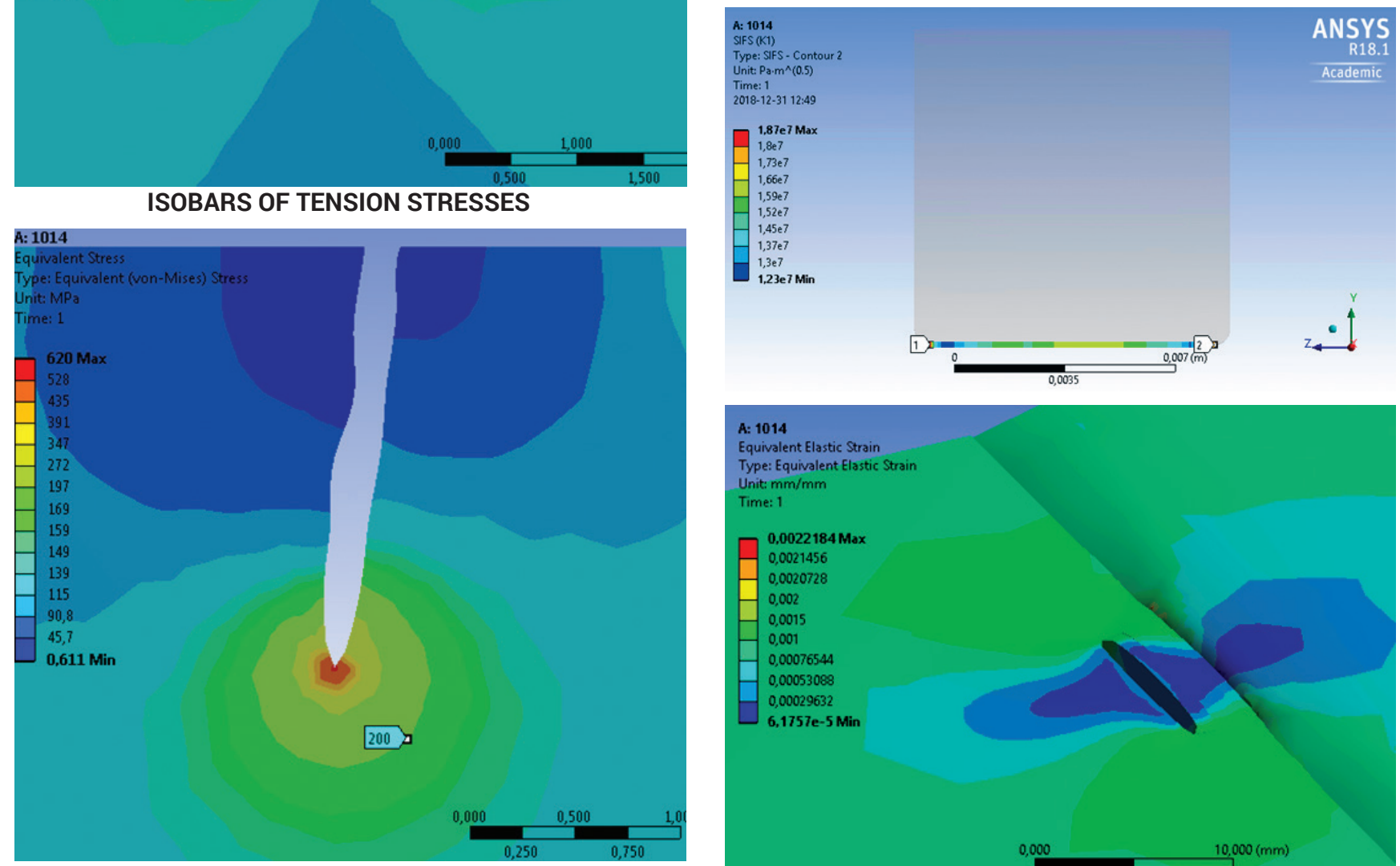

ISOBARS OF TORSION STRESSES

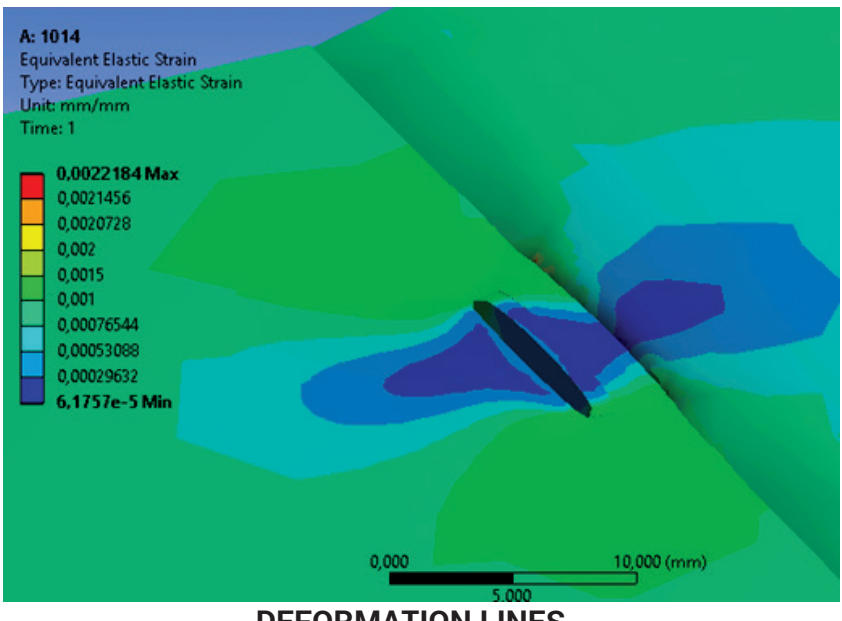

Fig. 6. The shape of the butt joint stress field for $50 \%$ WWN - cross-section
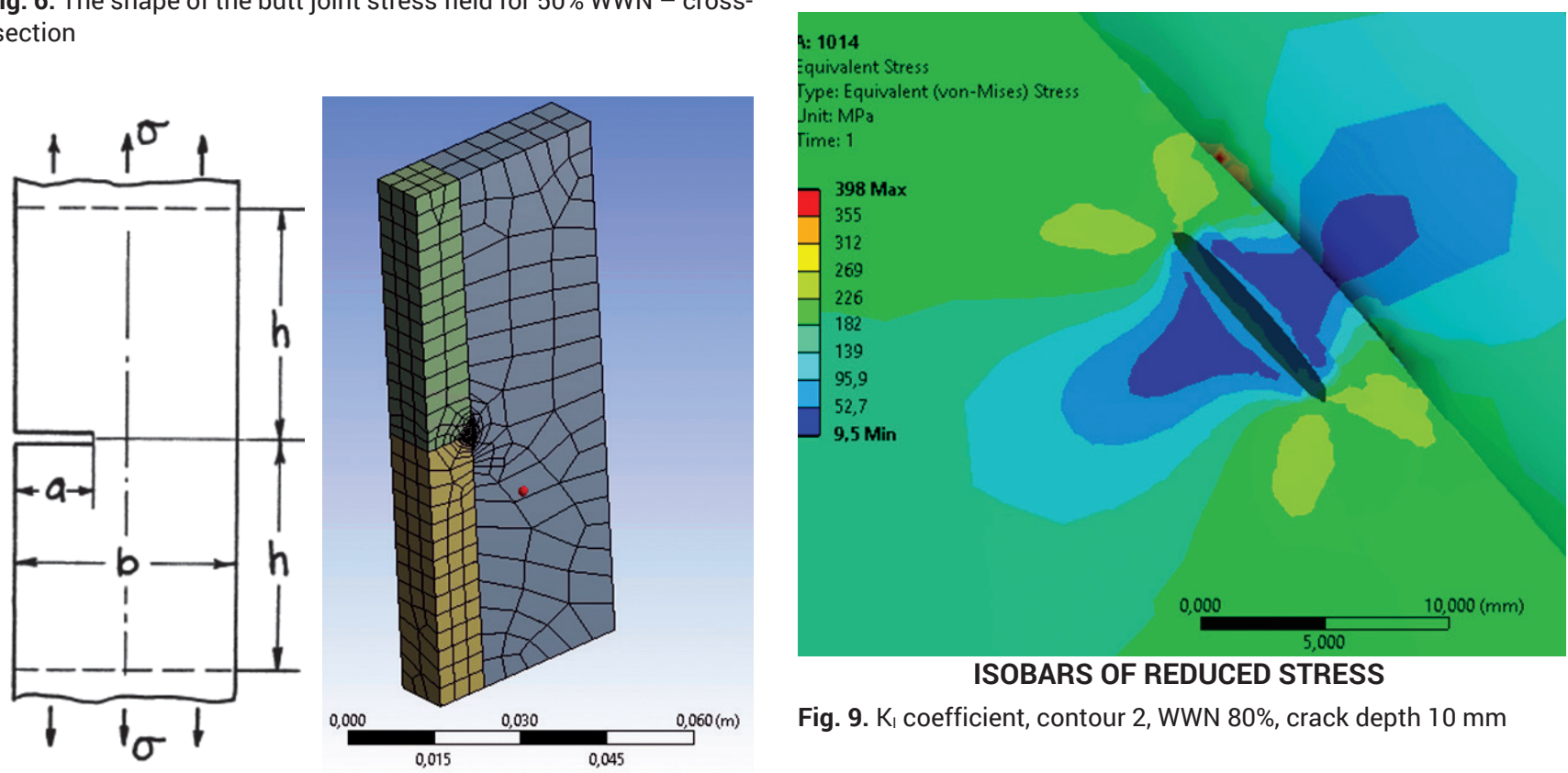

ISOBARS OF REDUCED STRESS

Fig. 9. $\mathrm{K}_{1}$ coefficient, contour 2 , WWN $80 \%$, crack depth $10 \mathrm{~mm}$

Fig. 7. The problem of fracture mechanics used to verify the program 
The values used for the simulation are: $a=10 \mathrm{~mm}, b=40 \mathrm{~mm}$ and $\mathrm{h}=100 \mathrm{~mm}$. For such values, the above pattern is reduced to the formula:

$\mathrm{K}_{\mathrm{l}}=0,265 \sigma$

Figure 8 shows a comparison graph for two values of stress intensity coefficients. Values calculated from formu-

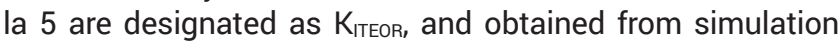
- $\mathrm{K}_{\text {ISYM. }}$. The analysis of the results allowed to estimate the maximum simulation error at $7.57 \%$, with a minimum of $2.70 \%$.

The stress intensity factors $\mathrm{K}_{1}, \mathrm{~K}_{\mathrm{II}}, \mathrm{K}_{\mathrm{III}}$, taking into account the shape of the body and the slit, as well as the combination of the load, is sufficient to fully describe the state of the stress field in front of the crack's tip. Figure 9 shows graphical simulation results of the setting with the force extending the discontinuity 1014 of the longitudinal crack in the basic material.

Figure 10 shows the values of the $K_{1}$ factor for individual contours. As described earlier, the results for contour 1, the nearest to the front of the crack, significantly differ from the others. For this reason, it was not taken into account and was given only for informational purposes. The $K_{1}$ factor is the smallest in the middle of the crack, the largest at both ends and shows a certain symmetry with respect to the centre of the crack. This is due to the existence of a PSS condition from the not cracked material adjacent to the crack, which by stiffening both ends of the crack generates a three-axis stress condition at both ends of the crack. This coincides with a lot of experimental data, which indicates that along the entire front of the crack, in its half the tension before

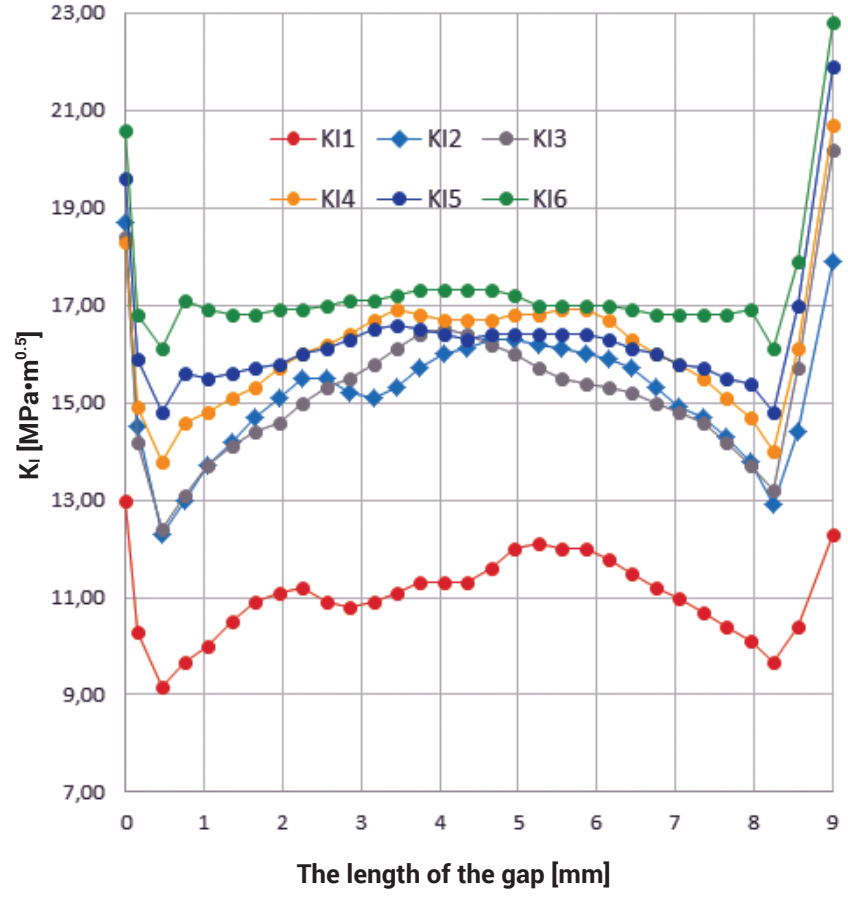

Fig. 10. Distribution of the coefficient $K_{1}$ for contours 1 to 6

the front of the crack is smaller than at its ends. It should be noted that in the available literature there are no calculated values of the $K_{1}$ factor for a gap which is not crossing throughout the entire thickness of the element.

\section{Conclusions}

1. The shape of the stress field generated by the discontinuity no 11014 significantly depends on the load combination.

2. From the fracture mechanic point of view the welded joint with discontinuity 1014 up to $20 \mathrm{~mm}$ depth will break in base material. In other words, the existence of discontinuity does not reduce the load capacity of the joint under static load conditions. The literature states that the stress intensity coefficient $\mathrm{K}_{\mathrm{IC}}$ applies to the crack depth value equal to $\sim 0.7$ of thickness of the native material. This means that for cracks more than $28 \mathrm{~mm}$ deep, the stress values obtained should not be taken into account. From the point of view of the fracture mechanics, there is a safe working area of the joint with a short discontinuity no. 1014 axially stretched. This is the area below the blue line in figure 4 limited to a depth of discontinuity of $20 \mathrm{~mm}$.

3. A series of joint simulations performed in various configurations of crack's depth-tensile stress shows that from the point of view of static loads there is a safe work area. However, it should be borne in mind that the acceptance of simulation results of stress reduced directly from the tip of discontinuity leads to significantly overstated results. Therefore, according to $\mathrm{H}-\mathrm{M}-\mathrm{H}$ hypothesis, it is proposed to use stress outside the plastic deformation zone.

\section{References}

[1] PN-EN 10025-2:2007 Wyroby walcowane na gorąco ze stali konstrukcyjnych Część 2: Warunki techniczne dostawy stali konstrukcyjnych niestopowych. 2007.

[2] PN-EN ISO 14341. Materiały dodatkowe do spawania. Druty elektrodowe i stopiwo do spawania łukowego elektrodą metalową w osłonie gazu stali niestopowych i drobnoziarnistych. Klasyfikacja. 2017.

[3] PN-EN ISO 5817 Spawanie. Złącza spawane ze stali, niklu i tytanu i ich stopów. Poziomy jakości według niezgodności spawalniczych. 2009.

[4] J. German, Podstawy mechaniki pękania, Politechnika Krakowska, Kraków, (2011).
[5] D. Roylance, Introduction to Fracture Mechanic, MIT, Cambrige (2001).

[6] J.W. Hutchinson, Fundamentals of the Phenomenological Theory of Nonlinear Fracture Mechanics, Journal of Appiled Mechanics, ASME (1981), Tom 50.

[7] PN-EN ISO 6892-1:2016-09. Metale. Próba rozciągania. Metoda badania w temperaturze pokojowej, PKN, Warszawa (2016).

[8] H. Tada, P.C. Paris i G.R. Irwin, The stress analysis of cracks handbook, ASME Press, New York (2000) 